\title{
Comparative study of dexamethasone and betamethasone for women at risk of preterm birth
}

\section{Jimitkumar J. Chhatrala*, Rutwa Chawada}

\author{
Department of Obstetrics and Gynaecology, SBKS Medical Institute and Research Centre, Pipariya, Waghodia, \\ Vadodara, Gujarat, India
}

Received: 30 April 2015

Revised: 12 July 2015

Accepted: 19 July 2015

\section{*Correspondence:}

Dr. Jimitkumar J. Chhatrala,

E-mail: jimitchhatrala@gmail.com

Copyright: $($ ) the author(s), publisher and licensee Medip Academy. This is an open-access article distributed under the terms of the Creative Commons Attribution Non-Commercial License, which permits unrestricted non-commercial use, distribution, and reproduction in any medium, provided the original work is properly cited.

\begin{abstract}
Background: Prematurity represents a serious problem for healthcare services throughout the world. Respiratory distress syndrome, neonatal death, intra-ventricular hemorrhage and low birth weight are continues to be the serious problems during the neonatal period, affecting a large number of premature infants. Dexamethasone and betamethasone are the two antenatal corticosteroids recommended for accelerating fetal lung development in threatened preterm birth.

Methods: This is a prospective comparative study conducted in the Department of Obstetrics and Gynecology, at Hiram Hospital, a tertiary care center situated in the rural area of Vadodara, in which 100 pregnant women of gestational age between 24 and 34 weeks with risk of preterm birth were taken as candidates for antenatal treatment with corticosteroids. Ethical approval was taken from the institutional ethical committee. Informed consent was taken from the patients. A detailed history and examination was done. 100 pregnant women of gestational age between 24 and 34 weeks with risk of preterm birth were selected randomly and divided into 2 groups of 50 each. Group A was given injection of dexamethasone $6 \mathrm{mg}$ intramuscularly 12 hours apart. Group B was given injection of betamethasone $12 \mathrm{mg}$ intramuscularly 24 hours apart. Patients were observed for neonatal death, respiratory distress syndrome, intraventricular hemorrhage and low birth weight.

Results: In our study there was no significant difference between the two groups in rate of neonatal mortality $(4 \% \mathrm{v} / \mathrm{s}$ $4 \%)$ and respiratory distress syndrome (38\% v/s 40\%). However, the rates of intra-ventricular hemorrhage $(6 \% \mathrm{v} / \mathrm{s}$ $12 \%)$ and low birth weight $(52 \% \mathrm{v} / \mathrm{s} 62 \%)$ were significantly low in neonates exposed to dexamethasone compared with betamethasone.
\end{abstract}

Conclusions: Dexamethasone is recommended over betamethasone for its efficacy, safety, wide availability and low cost for treatment of women at risk of preterm delivery.

Keywords: Dexamethasone, Betamethasone, Neonatal outcome

\section{INTRODUCTION}

Prematurity represents a serious problem for healthcare services throughout the world. The incidence of preterm birth accounts for $10-15 \%$ all over the world. Respiratory distress syndrome, neonatal death, intra-ventricular haemorrhage and low birth weight are continues to be the serious problems during the neonatal period, affecting a large number of premature infants.

Antenatal corticosteroids have been used since 1972 to accelerate foetal lung maturation in threatened pre-term birth. Dexamethasone and betamethasone are the two antenatal corticosteroids recommended for accelerating foetal lung development in threatened preterm birth. The 
WHO, ACOG and RCOG listed both dexamethasone and betamethasone as effective drugs for preventing complications of prematurity.

\section{Mechanism of action of Corticosteroids ${ }^{1}$ :}

Alveoli are lined with two types of cells, type 1 and type 2 pneumocytes. Type 1 pneumocytes are responsible for gaseous exchange in the alveoli. Type 2 pneumocytes are responsible for the production and secretion of surfactant. Antenatal corticosteroid therapy accelerates morphologic development of both types of alveolar cells. Flattening of epithelial cells, thinning of alveolar septa and increased cyto-differentiation is observed histologically. These changes increase maximal lung volume and compliance. Antenatal corticosteroids also regulate enzymes in type 2 pneumocytes that stimulate phospholipids synthesis and subsequent release of surfactant.

\section{Sequence of events ${ }^{1}$ :}

Free glucocorticoid enters the foetal type 2 pneumocytes and binds with intracellular glucocorticoid receptors. The steroid-receptor complex then binds with glucocorticoid response elements (GREs) located along the genome. There is increased transcription of certain genes and the resulting messenger ribonucleic acid (mRNA) is translated into specific enzymatic proteins. These enzymatic proteins stimulate phospholipids synthesis.

\section{METHODS}

This is a prospective comparative study conducted in the Department of Obstetrics and Gynecology, at Dhiraj Hospital, a tertiary care center situated in the rural area of Vadodara, in which 100 pregnant women of gestational age between 24 and 34 weeks with risk of preterm birth were taken as candidates for antenatal treatment with corticosteroids. Ethical approval was taken from the institutional ethical committee. Informed consent was taken from the patients.

A detailed history and examination was done. 100 pregnant women of gestational age between 24 and 34 weeks with risk of preterm birth were selected randomly and divided into 2 groups of 50 each. Group A was given injection of dexamethasone $6 \mathrm{mg}$ intramuscularly 12 hours apart. Group B was given injection of betamethasone $12 \mathrm{mg}$ intramuscularly 24 hours apart. Patients were observed for following neonatal outcomes:

1. Respiratory distress syndrome.

2. Neonatal death.

3. Intra-ventricular hemorrhage.

4. Low birth weight.

Group A and Group B were both comparable with regards to mean age, parity, and socio-economic status and haemoglobin levels.
Table 1: Baseline characteristics of study population.

\begin{tabular}{|lll|}
\hline Clinical profile & $\begin{array}{l}\text { Group A } \\
(\text { dexamethasone })\end{array}$ & $\begin{array}{l}\text { Group B } \\
(\mathrm{n}=50) \\
(\mathrm{n}=50)\end{array}$ \\
\hline Age & 24.3 & 24.5 \\
\hline Parity & 2 & 2 \\
\hline $\begin{array}{l}\text { Socio- } \\
\text { economic status }\end{array}$ & Lower & Lower \\
\hline $\begin{array}{l}\text { Hemoglobin } \\
(\%)\end{array}$ & 10.4 & 10.2 \\
\hline
\end{tabular}

\section{RESULTS}

Table no. 2 shows the comparison of results with dexamethasone and betamethasone groups for respiratory distress syndrome in neonates. In Group A, respiratory distress syndrome was noted in $20(40 \%)$ neonates, where as in Group B, respiratory distress syndrome was noted in $19(38 \%)$ neonates. Risk ratio was 1.05 .

Table 2: Comparison of dexamethasone and betamethasone for respiratory distress syndrome.

\begin{tabular}{|llll|}
\hline $\begin{array}{l}\text { Neonatal } \\
\text { outcome }\end{array}$ & $\begin{array}{l}\text { Group A } \\
(\text { dexamethasone })\end{array}$ & $\begin{array}{l}\text { Group B } \\
(\text { betamethasone }) \\
(\mathrm{n}=50)\end{array}$ & $\begin{array}{l}\text { Risk } \\
\text { ratio } \\
(95 \% \mathrm{CI})\end{array}$ \\
$\begin{array}{l}\text { Respiratory } \\
\text { distress } \\
\text { syndrome }\end{array}$ & $20(40 \%)$ & $19(38 \%)$ & 1.05 \\
\hline
\end{tabular}

Table no. 3 shows the comparison of results with dexamethasone and betamethasone groups for neonatal death. In both the groups neonatal death was same.

Table 3: Comparison of neonatal death between dexamethasone group and betamethasone group.

\begin{tabular}{|llll|}
\hline $\begin{array}{l}\text { Neonatal } \\
\text { outcome }\end{array}$ & $\begin{array}{l}\text { Group A } \\
(\text { dexamethasone) }\end{array}\left(\begin{array}{l}\text { Group B } \\
\text { (betamethasone) } \\
(n=50)\end{array}\right.$ & $\begin{array}{l}\text { Risk } \\
\text { ratio } \\
(95 \% \mathrm{CI})\end{array}$ \\
$\begin{array}{l}\text { Neonatal } \\
\text { death }\end{array}$ & $2(4 \%)$ & $2(4 \%)$ & 1.0 \\
\hline
\end{tabular}

Table no. 4 shows the comparison of results with dexamethasone and betamethasone groups for intraventricular haemorrhage in neonates. In Group A, intraventricular haemorrhage was noted in $3(6 \%)$ neonates, where as in Group B, intra-ventricular haemorrhage was noted in $6(12 \%)$ neonates. Risk ratio was 0.5 .

Table no. 5 shows the comparison of results with dexamethasone and betamethasone groups for low birth weight in neonates. In Group A, low birth weight was noted in $26(52 \%)$ neonates, where as in Group B, low birth weight was noted in $31(62 \%)$ neonates. Risk ratio was 0.83 . 
Table 4: Comparison of intra-ventricular hemorrhage between dexamethasone group and betamethasone group.

\begin{tabular}{|llll|} 
& $\begin{array}{l}\text { Group A } \\
\text { (dexamethason }\end{array}$ & $\begin{array}{l}\text { Group B } \\
\text { (betamethason }\end{array}$ & $\begin{array}{l}\text { Risk } \\
\text { ratio } \\
(95\end{array}$ \\
outcome & $\begin{array}{l}\text { e) } \\
(n=50)\end{array}$ & $\begin{array}{l}\% \\
(n=50)\end{array}$ \\
$\begin{array}{l}\text { Intra- } \\
\text { ventricular } \\
\text { hemorrhag } \\
\text { e }\end{array}$ & $3(6 \%)$ & $6(12 \%)$ & 0.5 \\
\hline
\end{tabular}

Table 5: Comparison of lower birth weight between dexamethasone and betamethasone group.

\begin{tabular}{|llll|}
\hline $\begin{array}{l}\text { Neonatal } \\
\text { outcome }\end{array}$ & $\begin{array}{l}\text { Group A } \\
(\text { dexamethasone }) \\
(\mathrm{n}=50)\end{array}$ & $\begin{array}{l}\text { Group B } \\
\text { (betamethasone) } \\
(\mathrm{n}=50)\end{array}$ & $\begin{array}{l}\text { Risk } \\
\text { ratio } \\
(95 \% \\
\mathrm{CI})\end{array}$ \\
\hline $\begin{array}{l}\text { Lower } \\
\text { birth } \\
\text { weight }\end{array}$ & $26(52 \%)$ & $31(62 \%)$ & 0.83 \\
\hline
\end{tabular}

\section{DISCUSSION}

In our study, there was no significant different between the two groups in rate of neonatal mortality $(4 \% \mathrm{v} / \mathrm{s} 4 \%)$ and respiratory distress syndrome (38\% v/s $40 \%)$.
However, the rates of intra-ventricular hemorrhage $(6 \%$ $\mathrm{v} / \mathrm{s} 12 \%)$ and lower birth weight (52\% v/s 62\%) were significantly lower in neonates exposed to dexamethasone compared with betamethasone.

1. Dexamethasone is five times more potent than betamethasone in non-genomic effects in addition to the stereoisomer difference of a methyl group at position 16 of ring $\mathrm{D}$ in their molecular structure. ${ }^{2,3}$

2. More rapid fall in fetal sheep progesterone levels is observed after betamethasone administration compared with dexamethasone. ${ }^{2,3}$

3. Cortisol levels continued to rise at 72 hours post exposure in the dexamethasone-treated fetal sheep. ${ }^{2,3}$

4. Dexamethasone was found to be superior to betamethasone in reducing the rate of intraventricular hemorrhage. The exact difference in physiologic responses of these stereoisomer molecules is not known and requires further investigation. $^{2,3}$

5. Dexamethasone causes less effect on fetal biophysical variables that might lead to premature intervention or delivery. ${ }^{2,3}$

Table no.6 shows comparison of our study with other studies for neonatal outcome for respiratory distress syndrome, neonatal death, intra-ventricular haemorrhage and low birth weight. Our study found that both betamethasone and dexamethasone are largely comparable in reducing most morbidities and mortality among preterm neonates. Our study is consistent with the reports of Elimian ${ }^{7,8}$ et al. \& Brown foot ${ }^{9,10}$ et al.

Table 6: Comparison with other studies.

\begin{tabular}{|c|c|c|c|c|c|}
\hline $\begin{array}{l}\text { NEONATAL OUTCOME } \\
\text { (Risk ratio) }\end{array}$ & $\begin{array}{l}\text { SUBTIL }^{4,5} \text { et } \\
\text { al. } 2003\end{array}$ & $\begin{array}{l}\text { CHEN }^{6} \text { et } \\
\text { al. } 2005\end{array}$ & $\begin{array}{l}\text { ELIMIAN } 7,8 \text { et } \\
\text { al. } 2007\end{array}$ & $\begin{array}{l}\text { BROWN FOOT,10 } \\
\text { et al. } 2013\end{array}$ & $\begin{array}{l}\text { OUR } \\
\text { STUDY }\end{array}$ \\
\hline Respiratory distress syndrome & & 0.94 & 1.10 & 1.08 & 1.05 \\
\hline Neonatal Death & 0.63 & & 1.22 & 1.12 & 1.0 \\
\hline Intra-ventricular Hemorrhage & & 0.71 & 0.34 & 0.44 & 0.5 \\
\hline Low birth weight & 0.89 & & & 0.89 & 0.83 \\
\hline
\end{tabular}

\section{CONCLUSIONS}

Dexamethasone is recommended over betamethasone for its efficacy, safety, wide availability and low cost for treatment of women at risk of preterm delivery.

Funding: No funding sources Conflict of interest: None declared

Ethical approval: The study was approved by the Institutional Ethics Committee

\section{REFERENCES}

1. Lee MJ, Guinn D. Antenatal use of glucocorticoids in women at risk for preterm delivery. Up-to-date journal 2015.

2. Derks JB, Giussani DA, Van Dam LM, Jenkins SL, Winter JA, Zhao XF, et al. Differential effects of betamethasone and dexamethasone fetal administration of parturition in sheep. J Soc Gynecol Investig. 1996;3:336-41.

3. Buttgereit F, Brand MD, Burmester GR. Equivalent doses and relative drug potencies for non-genomic glucocorticoid effects: a novel glucocorticoid hierarchy. Biochem Pharmacol. 1999;58:363-8. 
4. Subtil D, Tiberghien P, Devos P, Therby D, Leclerc $\mathrm{G}$, Vaast $\mathrm{P}$, et al. Immediate and delayed effects of antenatal corticosteroids on fetal heart rate: a randomized trial that compares betamethasone acetate and phosphate, betamethasone phosphate, and dexamethasone. American Journal of Obstetrics and Gynecology. 2003;188(2):524-31.

5. Subtil D, Tiberghien P, Leclercq G, Therby D, Dufour P, Puech F. Randomized trial comparing three different forms of antenatal corticotherapy on fetal heart rate. European Journal of Obstetrics, Gynecology, and Reproductive Biology. 2002;104:179.

6. Chen CY, Wang KG, Chang TY, Chen CP. Effects of antenatal betamethasone and dexamethasone in preterm neonates. Taiwanese Journal of Obstetrics and Gynaecology. 2005;44(3):247-51.

7. Elimian A, Garry D, Figueroa R, Spitzer A, Wiencek V. Antenatal betamethasone compared with dexamethasone (Betacode Trial): a randomized controlled trial. Obstetrics and Gynecology. 2007;110(1):26-30.
8. Elimian A, Garry D, Figueroa R, Spitzer AR, Wiencek V, Ogburn P, et al.'Betacode Trial' antenatal betamethasone compared to dexamethasone: a randomized controlled trial. American Journal of Obstetrics and Gynecology. 2005;193(6 Suppl):S5.

9. Brownfoot FC, Crowther CA, Middleton P. Different corticosteroids and regimens for accelerating fetal lung maturation for women at risk of preterm birth. Cochrane Database of Systematic Reviews 2008, Issue 4. [DOI:10.1002/14651858.CD006764.pub2]

10. Brownfoot FC, Crowther CA, Middleton P. Different corticosteroids and regimens for accelerating fetal lung maturation for women at risk of preterm birth. Cochrane Database of Systematic Reviews 2013, Issue 8 .

Cite this article as: Chhatrala JJ, Chawada R.

Comparative study of dexamethasone and betamethasone for women at risk of preterm birth. Int J Reprod Contracept Obstet Gynecol 2015;4:1000-3. 